Article

\title{
Impact of Different Positive End-Expiratory Pressures on Lung Mechanics in the Setting of Moderately Elevated Intra-Abdominal Pressure and Acute Lung Injury in a Porcine Model
}

\author{
Mascha O. Fiedler ${ }^{1,2, *} \mathbb{0}$, Emilis Simeliunas ${ }^{1,3}$, B. Luise Deutsch ${ }^{4}$, Dovile Diktanaite ${ }^{1,3}$, Alexander Harms ${ }^{5}$, \\ Maik Brune ${ }^{6}$, Maximilian Dietrich ${ }^{1}$, Florian Uhle ${ }^{1}\left({ }^{1}\right.$, Markus A. Weigand ${ }^{1,2}$ and Armin Kalenka ${ }^{2,7,8}{ }^{(1)}$
}

1 Department of Anesthesiology, Heidelberg University Hospital, 69120 Heidelberg, Germany; simeliunui@gmail.com (E.S.); diktanaite@gmail.com (D.D.); maximilian.dietrich@med.uni-heidelberg.de (M.D.); florian.uhle@med.uni-heidelberg.de (F.U.); Markus.weigand@med.uni-heidelberg.de (M.A.W.)

2 Translational Lung Research Center Heidelberg (TLRC), German Center for Lung Research (DZL), 69120 Heidelberg, Germany; armin.kalenka@kkh-bergstrasse.de

3 Department of Anesthesiology, Kantonsspital Lucerne, 6004 Lucerne, Switzerland

4 Faculty of Medicine, Justus Liebig University, 35392 Giessen, Germany; luisedeutsch@gmx.de

5 Institute of Pathology, University Hospital Heidelberg, 69120 Heidelberg, Germany; alexander.harms@med.uni-heidelberg.de

6 Department of Internal Medicine I and Clinical Chemistry, University Hospital Heidelberg, 69120 Heidelberg, Germany; maik.brune@med.uni-heidelberg.de

check for updates

Citation: Fiedler, M.O.; Simeliunas, E.; Deutsch, B.L.; Diktanaite, D.; Harms, A.; Brune, M.; Dietrich, M.; Uhle, F.; Weigand, M.A.; Kalenka, A. Impact of Different Positive EndExpiratory Pressures on Lung Mechanics in the Setting of Moderately Elevated IntraAbdominal Pressure and Acute Lung Injury in a Porcine Model. J. Clin. Med. 2021, 10, 306. https://doi.org/ $10.3390 / \mathrm{jcm} 10020306$

Received: 6 December 2020 Accepted: 12 January 2021 Published: 15 January 2021

Publisher's Note: MDPI stays neutral with regard to jurisdictional clai$\mathrm{ms}$ in published maps and institutional affiliations.

Copyright: () 2021 by the authors. Licensee MDPI, Basel, Switzerland. This article is an open access article distributed under the terms and conditions of the Creative Commons Attribution (CC BY) license (https:// creativecommons.org/licenses/by/ $4.0 /)$.
7 Department of Anesthesiology and Intensive Care Medicine, Hospital Bergstrasse, 64646 Heppenheim, Germany

8 Faculty of Medicine, University of Heidelberg, 69120 Heidelberg, Germany

* Correspondence: mascha.fiedler@med.uni-heidelberg.de

Abstract: The effects of a moderately elevated intra-abdominal pressure (IAP) on lung mechanics in acute respiratory distress syndrome (ARDS) have still not been fully analyzed. Moreover, the optimal positive end-expiratory pressure (PEEP) in elevated IAP and ARDS is unclear. In this paper, 18 pigs under general anesthesia received a double hit lung injury. After saline lung lavage and $2 \mathrm{~h}$ of injurious mechanical ventilation to induce an acute lung injury (ALI), an intra-abdominal balloon was filled until an IAP of $10 \mathrm{mmHg}$ was generated. Animals were randomly assigned to one of three groups (group $\mathrm{A}=$ PEEP 5, $\mathrm{B}=$ PEEP 10 and $\mathrm{C}=$ PEEP $15 \mathrm{cmH}_{2} \mathrm{O}$ ) and ventilated for $6 \mathrm{~h}$. We measured end-expiratory lung volume (EELV) per $\mathrm{kg}$ bodyweight, driving pressure $(\Delta \mathrm{P})$, transpulmonary pressure $\left(\Delta \mathrm{P}_{\mathrm{L}}\right)$, static lung compliance $\left(\mathrm{C}_{\text {stat }}\right)$, oxygenation $(\mathrm{P} / \mathrm{F}$ ratio $)$ and cardiac index (CI). In group $\mathrm{A}$, we found increases in $\Delta \mathrm{P}\left(22 \pm 1\right.$ vs. $\left.28 \pm 2 \mathrm{cmH}_{2} \mathrm{O} ; p=0.006\right)$ and $\Delta \mathrm{P}_{\mathrm{L}}\left(16 \pm 1\right.$ vs. $\left.22 \pm 2 \mathrm{cmH}_{2} \mathrm{O} ; p=0.007\right)$, with no change in $\mathrm{EELV} / \mathrm{kg}(15 \pm 1 \mathrm{vs} .14 \pm 1 \mathrm{~mL} / \mathrm{kg})$ when comparing hours 0 and 6 . In group $\mathrm{B}$, there was no change in $\Delta \mathrm{P}\left(26 \pm 2\right.$ vs. $\left.25 \pm 2 \mathrm{cmH}_{2} \mathrm{O}\right)$, $\Delta \mathrm{P}_{\mathrm{L}}\left(19 \pm 2\right.$ vs. $\left.18 \pm 2 \mathrm{cmH}_{2} \mathrm{O}\right), \mathrm{C}_{\text {stat }}\left(21 \pm 3\right.$ vs. $\left.21 \pm 2 \mathrm{cmH}_{2} \mathrm{O} / \mathrm{mL}\right)$ or $\mathrm{EELV} / \mathrm{kg}(12 \pm 2$ vs. $13 \pm 3 \mathrm{~mL} / \mathrm{kg}) . \Delta \mathrm{P}$ and $\Delta \mathrm{P}_{\mathrm{L}}$ were significantly lower after $6 \mathrm{~h}$ when comparing between group $\mathrm{C}$ and $\mathrm{A}\left(21 \pm 1\right.$ vs. $\left.28 \pm 2 \mathrm{cmH}_{2} \mathrm{O} ; p=0.020\right)$ and $\left(14 \pm 1\right.$ vs. $\left.22 \pm 2 \mathrm{cmH}_{2} \mathrm{O} ; p=0.013\right)$ ). The EELV $/ \mathrm{kg}$ increased over time in group C (13 \pm 1 vs. $19 \pm 2 \mathrm{~mL} / \mathrm{kg} ; p=0.034)$. The $\mathrm{P} / \mathrm{F}$ ratio increased in all groups over time. $\mathrm{CI}$ decreased in groups $\mathrm{B}$ and $\mathrm{C}$. The global lung injury score did not significantly differ between groups (A: $0.25 \pm 0.05, \mathrm{~B}: 0.21 \pm 0.02, \mathrm{C}: 0.22 \pm 0.03$ ). In this model of ALI, elevated IAP, $\triangle \mathrm{P}$ and $\Delta \mathrm{P}_{\mathrm{L}}$ increased further over time in the group with a PEEP of $5 \mathrm{cmH}_{2} \mathrm{O}$ applied over $6 \mathrm{~h}$. This was not the case in the groups with a PEEP of 10 and $15 \mathrm{cmH}_{2} \mathrm{O}$. Although $\Delta \mathrm{P}$ and $\Delta \mathrm{P}_{\mathrm{L}}$ were significantly lower after 6 hours in group $C$ compared to group A, we could not show significant differences in histological lung injury score.

Keywords: ALI; ARDS; intraabdominal pressure; PEEP; end-expiratory lung volume; transpulmonary pressure 


\section{Introduction}

The average intra-abdominal pressure (IAP) on admission of ventilated critical care patients in the intensive care unit is around $10 \mathrm{mmHg}$ [1]. The pressure in the abdomen causes a cranial shift of the diaphragm, thereby increasing intra-thoracic pressure and affecting lung volumes and respiratory mechanics [2,3]. The presence of intra-abdominal hypertension (IAH) is associated with a decrease in lung volume [4] and chest wall compliance [5]. An increasing degree of IAP results in a decline in lung volume [6,7], while decompressive laparotomy results in an improvement in lung volume [4]. Patients receiving mechanical ventilation are more likely to have IAH $[8,9]$. The presence of IAH may add to the development of ventilator-induced lung injury (VILI) [10]. In the setting of IAH, the lung will collapse at higher closing pressures during expiration. In the context of IAH, increased atelectrauma due to increased atelectasis formation and an insufficient positive end-expiratory pressure (PEEP) may further accelerate lung injury [2,3,11].

Nearly every fourth patient requiring mechanical ventilation has acute respiratory distress syndrome (ARDS) [12]. The presence of ARDS appears to strongly influence how IAP affects respiratory mechanics and oxygenation [3].

The best procedure to set PEEP in patients with ARDS is still a matter of debate [13]. Determining the best PEEP to be used during increasing abdominal pressure and ARDS remains unknown and PEEP settings in clinical routines can be even more challenging.

We therefore studied the effect of a moderately elevated IAP of $10 \mathrm{mmHg}$ on lung mechanics in a porcine ALI model up to $6 \mathrm{~h}$. To investigate the consequences of different PEEP levels, we used three levels of PEEP $\left(5,10,15 \mathrm{cmH}_{2} \mathrm{O}\right)$. The hypothesis in our study was that a PEEP of $15 \mathrm{cmH}_{2} \mathrm{O}$ in moderately elevated IAP $(10 \mathrm{mmHg})$ would be protective by reducing driving pressure and transpulmonary pressures, as well as preserving the EELV during mechanical ventilation.

\section{Materials and Methods}

\subsection{Animal Preparation and Instrumentation}

The protocol was approved by the responsible committee for animal research (Regierungspräsidium Karlsruhe, No. 35-9185.81/G-161/17). We included 18 female German landracer swines in this study with a weight of $50 \pm 3 \mathrm{~kg}$. After induction of anesthesia, the pigs were ventilated with an intensive care ventilator (Carescape R860, GE Healthcare, Madison, USA) using an inspiratory oxygen concentration $\left(\mathrm{F}_{\mathrm{i}} \mathrm{O}_{2}\right)$ of 0.4 in a pressure-controlled mode with volume guaranty. Also, a tidal volume of $8 \mathrm{~mL} / \mathrm{kg}$ bodyweight (bw), an inspiration/expiration ratio (I:E) of 1:2 and a PEEP of $5 \mathrm{cmH}_{2} \mathrm{O}$ was provided. The respiratory rate was adjusted to $\mathrm{p}_{\mathrm{a}} \mathrm{CO}_{2}$ (normocapnia). Anesthesia was maintained by continuous infusion of $6 \mathrm{mg} / \mathrm{kg} / \mathrm{h}$ Ketanest $S$ (Pfizer Pharma, Berlin, Germany), $3.6 \mathrm{mg} / \mathrm{kg} / \mathrm{h}$ midazolam and $10-30 \mathrm{mg} / \mathrm{kg} / \mathrm{h}$ propofol 2\% (Propofol, Fresenius Kabi, Bad Homburg, Germany). There was no use of neuromuscular blockers. Adequacy of the depth of anesthesia was regularly assessed by the absence of spontaneous breathing efforts and lack of muscle tone. No recruitment maneuvers were applied through the study period. Throughout the whole experiment, pigs were kept in a supine position.

A 5 French catheter was inserted with ultrasound guidance (VScan ${ }^{\circledR}$, GE Ultrasound, Horten, Norway) in the femoral artery for measurement of invasive blood pressure and cardiac index $(\mathrm{CI})\left(\mathrm{PiCCO}^{\circledR}\right.$, Pulsion Medical systems, Feldkirchen, Germany). A threelumen catheter (Logicath ${ }^{\circledR}$, Smiths Medical, Grasbrunn, Germany) was inserted with ultrasound guidance in the right external jugular vein. Crystalloid solution (Sterofundin ${ }^{\circledR}$, Braun, Melsungen, Germany) was infused at a rate of $10 \mathrm{~mL} / \mathrm{kg}$ for the first hour, and thereafter the infusion rate was kept at $10-40 \mathrm{~mL} / \mathrm{kg} / \mathrm{h}$ to maintain hemodynamic stability during the experiment. A polyethylene catheter with a thin walled latex balloon (Nutrivent multifunction nasogastric catheter, Sidam, San Glacomo Roncole, Italy) was passed via the snout into the stomach. The catheter was connected to the pressure-port of the ventilator for measuring esophageal pressure $\left(\mathrm{P}_{\mathrm{Es}}\right)$. After inflating the balloon with $3 \mathrm{~mL}$ of air, it was withdrawn into the esophagus. Appropriate catheter position was confirmed by 
visualization of cardiac artefacts on the $\mathrm{P}_{\mathrm{Es}}$ curve on the ventilator and further confirmed by an occlusion test [14].

After a midline laparotomy, a large intra-abdominal balloon (200 L weather balloon, Stratoflight, Blomberg, Germany) was placed in the peritoneal cavity. Correct position in all abdominal quadrants was ensured by visual inspection and partial inflation. The abdomen was carefully closed. A urine catheter was placed in the bladder and connected to an intra-abdominal pressure device (UnoMeter ${ }^{\circledR}$ Abdo-Pressure, Birkerod, Denmark).

Acute lung injury was established by using $0.9 \%$ sodium chloride warmed to body temperature, instilled into the endotracheal tube, and then drained by gravity [15]. The animals remained in a supine position and saline lung lavage was repeatedly performed until a ratio of partial arterial pressure of oxygen to inspired oxygen $(\mathrm{P} / \mathrm{F}$ ratio $)<150 \mathrm{mmHg}$ was reached for at least $30 \mathrm{~min}$. Thereafter, an injurious mechanical ventilation was applied (pressure controlled ventilation: peak inspiratory airway pressure $\left(\mathrm{P}_{\text {Insp }}\right): 35 \mathrm{cmH}_{2} \mathrm{O}, \mathrm{PEEP}$ : $0 \mathrm{cmH}_{2} \mathrm{O}$, respiratory rate (RR): $12 /$ minute, I:E: $1: 2$ and $\mathrm{F}_{\mathrm{i}} \mathrm{O}_{2}: 1.0$ for $120 \mathrm{~min}$.

\subsection{Measurements and Calculations}

Peak inspiratory airway pressure, $\mathrm{PEEP}$, inspiratory esophageal pressure $\left(\mathrm{P}_{\mathrm{EsInsp}}\right)$ and end-expiratory esophageal pressure $\left(\mathrm{P}_{\mathrm{EsExp}}\right)$ were recorded from the ventilator. $\Delta \mathrm{P}$ and $\Delta \mathrm{P}_{\mathrm{L}}$ were calculated as previously described [16]. Transpulmonary inspiratory pressure $\left(\mathrm{TPP}_{\text {Insp }}\right)$ was calculated as $\mathrm{TTP}_{\text {Insp }}=\mathrm{P}_{\text {Insp }}-\mathrm{P}_{\text {EsInsp }}$ and transpulmonary expiratory pressure $\left(\mathrm{TPP}_{\mathrm{Exp}}\right)$ as $\mathrm{TPP}_{\mathrm{Exp}}=\mathrm{PEEP}-\mathrm{P}_{\mathrm{EsExp}} \cdot \mathrm{C}_{\mathrm{Stat}}$ was measured by the ventilator during an inspiratory hold. Elastance of the respiratory system $\left(\mathrm{E}_{\mathrm{RS}}\right)$ was calculated as $\mathrm{E}_{\mathrm{RS}}=\left(\mathrm{P}_{\mathrm{Insp}}\right.$ $-\mathrm{PEEP}) / \mathrm{V}_{\mathrm{T}}$, chest wall elastance $\left(\mathrm{E}_{\mathrm{CW}}\right)$ as $\mathrm{E}_{\mathrm{CW}}=\left(\mathrm{P}_{\mathrm{EsInsp}}-\mathrm{P}_{\mathrm{EsExp}}\right) / \mathrm{V}_{\mathrm{T}}$ and elastance of the lung $\left(\mathrm{E}_{\mathrm{L}}\right)$ as $\mathrm{E}_{\mathrm{L}}=\mathrm{E}_{\mathrm{RS}}-\mathrm{E}_{\mathrm{CW}}$.

We measured EELV bedside without interruption of mechanical ventilation using the modified nitrogen multiple breath (NMBW) technique [17], which is integrated in the intensive care ventilator. We performed 3 wash-out/wash-in cycles and averaged them within a $10 \%$ range. Cardiac index $(\mathrm{CI})$ was calculated with the $\mathrm{PiCCO}^{\circledR}$ System.

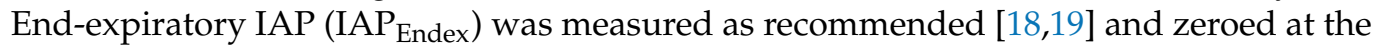
midaxillary level [20]. P/F ratio was calculated based on the ratio of partial arterial pressure of oxygen to $\mathrm{F}_{\mathrm{i}} \mathrm{O}_{2}$.

\subsection{Experimental Protocol}

After initial instrumentation, the pigs were stabilized for $30 \mathrm{~min}$ and baseline measurements were taken. After induction of acute lung injury by saline lung lavage and $120 \mathrm{~min}$ injurious mechanical ventilation, we changed ventilator parameters to baseline settings and measured values for hour 0 (H0).

The abdominal balloon was then filled with water up to an $\mathrm{IAP}_{\text {Endex }}$ of $10 \mathrm{mmHg}$. The animals were then randomized into group $\mathrm{A}(n=6)$ with a PEEP of $5 \mathrm{cmH}_{2} \mathrm{O}$, group $\mathrm{B}$ $(n=6)$ with a PEEP of $10 \mathrm{cmH}_{2} \mathrm{O}$, or group $\mathrm{C}(n=6)$ with a PEEP of $15 \mathrm{cmH}_{2} \mathrm{O}$ for $6 \mathrm{~h}(\mathrm{H} 6)$ (Figure 1). The $\mathrm{F}_{\mathrm{i}} \mathrm{O}_{2}$ was kept between 0.4 and 0.7 to reach a saturation higher than $85 \%$.

At the end of the experimental protocol, the pigs were euthanized. We exposed the complete right lung and regional lung samples for extraction to evaluate the wet-dry weight ratio and to perform histological examinations. 


\section{8 pigs}

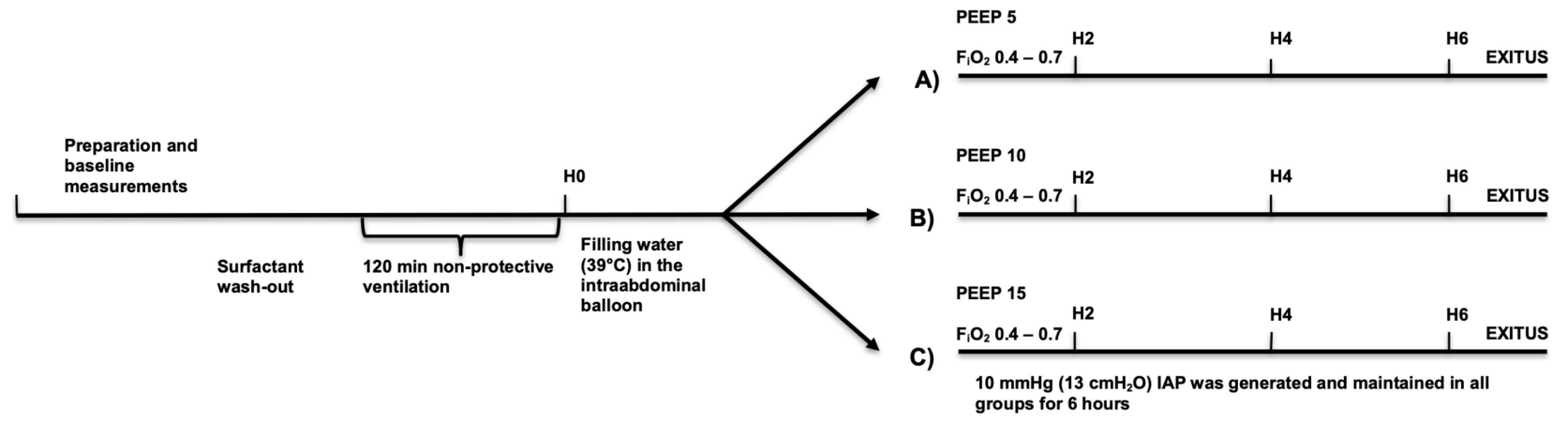

Figure 1. Experimental timeline. H0, H2, H4, H6-hours after lung injury (wash out and injurious ventilation), PEEPpositive end expiratory pressure, $\mathrm{FiO}_{2}$ —oxygen fraction, $\mathrm{IAP}$-intra-abdominal pressure, (A)—group A, (B)—group B, (C)-group C.

\subsection{Histology}

Samples from the anterior, medial and dorsal position of the medial lobe were selected and immediately fixed in formalin. After fixation, the tissue samples were dehydrated and embedded. The sections were stained with hematoxylin and eosin. A pathologist, blinded to the study variables, evaluated each sample histologically to determine a lung injury score. To quantify the extent of histologic lung injury, the pathologist used a lung injury scoring system [21] (Supplementary Figure S1). Five independent variables were scored to generate the lung injury score. The sum of each of the five independent variables were weighted according to the relevance for acute lung injury [21]. The resulting lung injury score ranges from 0 to 1 . Zero represents minimal to no damage and 1 represents the worst damage possible (Supplementary Figure S2).

\subsection{Wet-To-Dry Ratio}

Wet-dry weight ratio was measured in samples from the medial lobe. Samples were weighted, dried and then weighted again. We dried the lung samples for $72 \mathrm{~h}$ in an oven at $80^{\circ} \mathrm{C}$.

\subsection{Statistical Analysis}

Sample size was calculated based on expected alterations in end-expiratory lung volume (EELV) from data from previous studies [22] and unpublished data in our lab between a PEEP level of 5 and $10 \mathrm{cmH}_{2} \mathrm{O}$. To identify a significant difference in EELV based on an alpha $=0.05$ and a power $=80 \%$, a sample size of $n=6$ per group was calculated to be sufficient. We used the free software $G^{*}$ Power 3 to calculate the sample size [23].

Statistical analysis was performed using SPSS (version 25). Baseline data and H0 values were analyzed with the Shapiro-Wilk test for normal distribution. In case of normally distributed data, a one-way ANOVA was performed. In case of significance, a post hoc analysis with a Games-Howell correction for multiple tests was performed. We used a paired sample t-test to compare baseline with $\mathrm{H} 0$ data and $\mathrm{H} 0$ with $\mathrm{H} 6$ data within one group. Non-normally distributed data were analyzed using non-parametric tests.

To compare $\mathrm{H} 0$ with $\mathrm{H} 6$, data between all groups were used to calculate the difference between $\mathrm{H} 6$ and $\mathrm{H} 0$, followed by one-way ANOVA. In case of significance, post-hoc analyses with a Games-Howell correction for multiple tests were performed.

To demonstrate the impact of the different PEEP levels over six hours of ventilation, we generated the pulmonary and hemodynamic parameters by the subtraction of $\mathrm{H} 0$ from H6. A positive result was interpreted as an increase in this parameter.

Data are expressed as mean \pm standard error of the mean (SEM) in cases of non-normal distribution, otherwise as median and interquartile range (IQR). For all tests, $p<0.05$ was considered statistically significant. 


\section{Results}

After induction of acute lung injury at $\mathrm{H} 0$, there were several significant changes in values compared with baseline data (Table 1): a reduction in EELV(1269 \pm 68 vs. $665 \pm 54$; $p<0.010), \mathrm{C}_{\text {stat }}(42 \pm 2$ vs. $21 \pm 1 ; p<0.013)$ and $\mathrm{P} / \mathrm{F}$ ratio $(456 \pm 13$ vs. $110 \pm 13 ; p<0.012)$ were seen, as well as an increase in $\Delta \mathrm{P}(12 \pm 0$ vs. $26 \pm 1 ; p<0.009)$ and $\Delta \mathrm{P}_{\mathrm{L}}(6 \pm 0$ vs. $19 \pm 1 ; p<0.011)$.

Table 1. Pulmonary and hemodynamic parameters after induction of acute lung injury at H0 compared with baseline data.

\begin{tabular}{ccc}
\hline & Baseline & H0 \\
\hline IAP & $2.3 \pm 0.3$ & $3.2 \pm 0.3^{*}$ \\
\hline EELV & $1269 \pm 68$ & $665 \pm 54^{*}$ \\
\hline EELV $/ \mathrm{kg}$ & $25 \pm 1$ & $13 \pm 1^{*}$ \\
\hline$\Delta \mathrm{P}$ & $12 \pm 0$ & $26 \pm 1^{*}$ \\
\hline$\Delta \mathrm{P}_{\mathrm{L}}$ & $6 \pm 0$ & $19 \pm 1^{*}$ \\
\hline $\mathrm{TPP}$ Insp & $6 \pm 1$ & $17 \pm 1^{*}$ \\
\hline $\mathrm{TPP}_{\mathrm{Exp}}$ & $0 \pm 0$ & $-2 \pm 1^{*}$ \\
\hline $\mathrm{C}_{\text {stat }}$ & $42 \pm 2$ & $21 \pm 1^{*}$ \\
\hline $\mathrm{E}_{\mathrm{RS}}$ & $30 \pm 1$ & $65 \pm 4^{*}$ \\
\hline $\mathrm{E}_{\mathrm{CW}}$ & $15 \pm 1$ & $18 \pm 1^{*}$ \\
\hline $\mathrm{E}_{\mathrm{L}}$ & $15 \pm 1$ & $47 \pm 4^{*}$ \\
\hline $\mathrm{HR}$ & $66 \pm 3$ & $83 \pm 5^{*}$ \\
\hline $\mathrm{MAP}$ & $84 \pm 2$ & $101 \pm 2^{*}$ \\
\hline $\mathrm{P} / \mathrm{F} \mathrm{ratio}$ & $456 \pm 13$ & $110 \pm 13^{*}$ \\
\hline $\mathrm{CI}$ & $4.2 \pm 0.2$ & $4.7 \pm 0.2$ \\
\hline Lactate & $1.4 \pm 0.2$ & $1.4 \pm 0.1$ \\
\hline $\mathrm{pH}$ & $7.45 \pm 0.01$ & $7.37 \pm 0.01$ \\
\hline $\mathrm{RR}$ & $20(0)$ & $24(4)$ \\
\hline
\end{tabular}

$n=18$, data are expressed as mean \pm standard error of the mean (SEM) with the exception of respiratory rate (RR) which is expressed as median (IQR). IAP = intra-abdominal pressure (mmHg), EELV = end-expiratory lung volume $(\mathrm{mL}), \mathrm{EELV} / \mathrm{kg}$ = end-expiratory lung volume per $\mathrm{kg}$ bodyweight $(\mathrm{ml} / \mathrm{kg}), \Delta \mathrm{P}=$ driving pressure $\left(\mathrm{cmH}_{2} \mathrm{O}\right), \Delta \mathrm{P}_{\mathrm{L}}=$ transpulmonary pressure $\left(\mathrm{cmH}_{2} \mathrm{O}\right), \mathrm{TPP}_{\text {Insp }}=$ inspiratory transpulmonary pressure $\left(\mathrm{cmH}_{2} \mathrm{O}\right)$, $\mathrm{TPP}_{\mathrm{Exp}}=$ expiratory transpulmonary pressure $\left(\mathrm{cmH}_{2} \mathrm{O}\right), \mathrm{C}_{\text {Stat }}=$ static pulmonary compliance $\left(\mathrm{mL} / \mathrm{cmH}_{2} \mathrm{O}\right)$, $\mathrm{E}_{\mathrm{RS}}=$ elastance of the respiratory system $\left(\mathrm{cmH}_{2} \mathrm{O} / \mathrm{mL}\right), \mathrm{E}_{\mathrm{CW}}=$ elastance of the chest wall $\left(\mathrm{cmH}_{2} \mathrm{O} / \mathrm{mL}\right), \mathrm{E}_{\mathrm{L}}=$ lung elastance $\left(\mathrm{cmH}_{2} \mathrm{O} / \mathrm{mL}\right), \mathrm{HR}=$ heart rate (beats $\left./ \mathrm{min}\right), \mathrm{MAP}=$ mean arterial pressure $(\mathrm{mmHg}), \mathrm{P} / \mathrm{F}$ ratio = ratio between arterial pressure of oxygen and inspired oxygen concentration $(\mathrm{mmHg}), \mathrm{CI}=$ cardiac index $\left(\mathrm{L} / \mathrm{min} / \mathrm{m}^{2}\right)$, Lactate $(\mathrm{mmol} / \mathrm{L}) .{ }^{*} p<0.05$.

When compared with data at $\mathrm{H} 0$, we observed several significant alterations in the setting of $6 \mathrm{~h}$ of mechanical ventilation with an intra-abdominal pressure of $10 \mathrm{mmHg}$ and acute lung injury (H6). The EELV and EELV $/ \mathrm{kg}$ increased in group C (EELV: $633 \pm 39$ vs. $976 \pm 119 \mathrm{~mL} ; p=0.029$ and EELV $/ \mathrm{kg}$ bw: $13 \pm 1$ vs. $19 \pm 2 \mathrm{~mL} / \mathrm{kg} ; p=0.034)$ but did not change in groups $\mathrm{A}$ and $\mathrm{B}$ (Table 2 and Figure 2). The $\Delta \mathrm{P}$ increased in group A over time ( $22 \pm 1$ vs. $28 \pm 2 ; p=0.006$ ) whereas it decreased (without significance) with a PEEP of $15 \mathrm{cmH}_{2} \mathrm{O}$ in group $\mathrm{C}(29 \pm 3$ vs. $21 \pm 1 ; p=0.081)$ and showed significantly lower values than group A at H6 (C: $21 \pm 1$ vs A: $28 \pm 2 ; p=0.020$ ) (Table 2 and Figure 3 ). 
Table 2. Pulmonary and hemodynamic parameters in the setting of $6 \mathrm{~h}$ of mechanical ventilation with an intra-abdominal pressure of $10 \mathrm{mmHg}$ and acute lung injury.

\begin{tabular}{|c|c|c|c|c|}
\hline & & Group A $(n=6)$ & Group B $(n=6)$ & Group C $(n=6)$ \\
\hline Weight (kg) & Baseline & $51 \pm 3$ & $49 \pm 3$ & $51 \pm 3$ \\
\hline PEEP & & 5 & 10 & 15 \\
\hline IAP & $\mathrm{HO}$ & $3 \pm 1$ & $3 \pm 0$ & $4 \pm 1$ \\
\hline IAP & $\mathrm{H} 6$ & $10 \pm 1 *$ & $10 \pm 0$ * & $10 \pm 0$ * \\
\hline EELV & $\mathrm{HO}$ & $782 \pm 105$ & $579 \pm 114$ & $633 \pm 39$ \\
\hline EELV & H6 & $736 \pm 152$ & $680 \pm 153$ & $976 \pm 119 *$ \\
\hline $\mathrm{EELV} / \mathrm{kg}$ & $\mathrm{HO}$ & $15 \pm 1$ & $12 \pm 2$ & $13 \pm 1$ \\
\hline $\mathrm{EELV} / \mathrm{kg}$ & H6 & $14 \pm 2$ & $13 \pm 3$ & $19 \pm 2 *$ \\
\hline$\Delta \mathrm{P}$ & Ho & $22 \pm 1$ & $26 \pm 2$ & $29 \pm 3$ \\
\hline$\Delta \mathrm{P}$ & H6 & $28 \pm 2 * \S$ & $25 \pm 2$ & $21 \pm 1$ \\
\hline$\Delta \mathrm{P}_{\mathrm{L}}$ & $\mathrm{HO}$ & $16 \pm 1$ & $19 \pm 2$ & $21 \pm 3$ \\
\hline$\Delta \mathrm{P}_{\mathrm{L}}$ & H6 & $22 \pm 2 * \S$ & $18 \pm 2$ & $14 \pm 1$ \\
\hline $\mathrm{TPP}_{\text {Insp }}$ & $\mathrm{HO}$ & $15 \pm 1$ & $17 \pm 3$ & $20 \pm 2$ \\
\hline $\mathrm{TPP}_{\text {Insp }}$ & H6 & $19 \pm 2 *$ & $18 \pm 2$ & $18 \pm 1$ \\
\hline $\mathrm{TPP}_{\text {Exp }}$ & $\mathrm{Ho}$ & $-2 \pm 0$ & $-3 \pm 1$ & $-1 \pm 1$ \\
\hline $\mathrm{TPP}_{\operatorname{Exp}}$ & H6 & $-2 \pm 1^{\S}$ & $-1 \pm 0^{\$}$ & $3 \pm 1$ * \\
\hline $\mathrm{C}_{\text {stat }}$ & $\mathrm{HO}$ & $22 \pm 1$ & $21 \pm 3$ & $19 \pm 2$ \\
\hline $\mathrm{C}_{\text {stat }}$ & H6 & $18 \pm 1 * \S$ & $21 \pm 2$ & $24 \pm 2 *$ \\
\hline $\mathrm{E}_{\mathrm{RS}}$ & $\mathrm{HO}$ & $56 \pm 3$ & $67 \pm 7$ & $72 \pm 9$ \\
\hline $\mathrm{E}_{\mathrm{RS}}$ & $\mathrm{H} 6$ & $69 \pm 5 * \S$ & $66 \pm 7$ & $53 \pm 5$ \\
\hline $\mathrm{E}_{\mathrm{CW}}$ & $\mathrm{HO}$ & $16 \pm 2$ & $17 \pm 2$ & $21 \pm 2$ \\
\hline $\mathrm{E}_{\mathrm{CW}}$ & H6 & $16 \pm 2$ & $18 \pm 1$ & $17 \pm 2 *$ \\
\hline $\mathrm{E}_{\mathrm{L}}$ & $\mathrm{HO}$ & $40 \pm 2$ & $50 \pm 7$ & $52 \pm 8$ \\
\hline $\mathrm{E}_{\mathrm{L}}$ & H6 & $54 \pm 5^{* \S}$ & $48 \pm 7$ & $35 \pm 2$ \\
\hline HR & $\mathrm{Ho}$ & $70 \pm 8$ & $84 \pm 11$ & $93 \pm 7$ \\
\hline HR & H6 & $88 \pm 6$ & $84 \pm 9$ & $75 \pm 4$ \\
\hline MAP & $\mathrm{Ho}$ & $101 \pm 4$ & $99 \pm 2$ & $104 \pm 6$ \\
\hline MAP & H6 & $108 \pm 5$ & $99 \pm 5$ & $97 \pm 3$ \\
\hline $\mathrm{P} / \mathrm{F}$ ratio & $\mathrm{Ho}$ & $130 \pm 22$ & $120 \pm 27$ & $81 \pm 19$ \\
\hline $\mathrm{P} / \mathrm{F}$ ratio & H6 & $196 \pm 39 *$ & $240 \pm 55^{*}$ & $320 \pm 56$ * \\
\hline $\mathrm{p}_{\mathrm{a}} \mathrm{CO}_{2}$ & $\mathrm{HO}$ & $38 \pm 2$ & $40 \pm 2$ & $39 \pm 2$ \\
\hline $\mathrm{p}_{\mathrm{a}} \mathrm{CO}_{2}$ & H6 & $42 \pm 1$ & $39 \pm 1$ & $38 \pm 1$ \\
\hline $\mathrm{CI}$ & $\mathrm{HO}$ & $4.5 \pm 0.4$ & $4.4 \pm 0.3$ & $5.2 \pm 0.4$ \\
\hline $\mathrm{CI}$ & H6 & $4.2 \pm 0.1^{\S}$ & $3.9 \pm 0.2 *$ & $3.7 \pm 0.1 *$ \\
\hline Lactate & H0 & $1.3 \pm 0.3$ & $1.3 \pm 0.2$ & $1.6 \pm 0.3$ \\
\hline Lactate & H6 & $0.6 \pm 0.1$ & $0.6 \pm 0.1^{*}$ & $0.8 \pm 0.1$ \\
\hline $\mathrm{pH}$ & $\mathrm{HO}$ & $7.38 \pm 0.02$ & $7.36 \pm 0.01$ & $7.38 \pm 0.02$ \\
\hline
\end{tabular}


Table 2. Cont.

\begin{tabular}{ccccc}
\hline & & Group A $(\boldsymbol{n}=\mathbf{6})$ & Group B $(\boldsymbol{n}=\mathbf{6})$ & Group C $(\boldsymbol{n}=\mathbf{6})$ \\
\hline $\mathrm{pH}$ & $\mathrm{H} 6$ & $7.44 \pm 0.04$ & $7.44 \pm 0.01$ & $7.45 \pm 0.01$ \\
\hline $\mathrm{RR}$ & $\mathrm{H} 0$ & $23 \pm 1$ & $23 \pm 1$ & $25 \pm 1$ \\
\hline $\mathrm{RR}$ & $\mathrm{H} 6$ & $25 \pm 1^{*}$ & $25 \pm 1$ & $25 \pm 1$ \\
\hline Crystalloid volume & H6 & $4.9 \pm 0.4 \S$ & $5.9 \pm 0.6$ & $7.1 \pm 0.6$ \\
\hline
\end{tabular}

Data are expressed as mean \pm SEM. PEEP = positive end-expiratory pressure $\left(\mathrm{cmH}_{2} \mathrm{O}\right)$, IAP = intra-abdominal pressure $(\mathrm{mmHg}), \mathrm{EELV}=$ end-expiratory lung volume $(\mathrm{mL}), \mathrm{EELV} / \mathrm{kg}=$ end-expiratory lung volume per $\mathrm{kg}$ bodyweight $(\mathrm{mL} / \mathrm{kg}), \Delta \mathrm{P}=$ driving pressure $\left(\mathrm{cmH}_{2} \mathrm{O}\right), \Delta \mathrm{P}_{\mathrm{L}}=$ transpulmonary pressure $\left(\mathrm{cmH}_{2} \mathrm{O}\right), \mathrm{TPP}_{\text {Insp }}=$ inspiratory transpulmonary pressure $\left(\mathrm{cmH}_{2} \mathrm{O}\right), \mathrm{TPP}_{\mathrm{Exp}}=$ expiratory transpulmonary pressure $\left(\mathrm{cmH}_{2} \mathrm{O}\right), \mathrm{C}_{\text {Stat }}=$ static pulmonary compliance $\left(\mathrm{mL} / \mathrm{cmH}_{2} \mathrm{O}\right), \mathrm{E}_{\mathrm{RS}}=$ elastance of the respiratory system $\left(\mathrm{cmH}_{2} \mathrm{O} / \mathrm{mL}\right), \mathrm{E}_{\mathrm{CW}}=$ elastance of the chest wall $\left(\mathrm{cmH}_{2} \mathrm{O} / \mathrm{mL}\right), \mathrm{EL}=$ lung elastance $\left(\mathrm{cmH}_{2} \mathrm{O} / \mathrm{mL}\right), \mathrm{HR}=$ heart rate (beats $\left./ \mathrm{min}\right), \mathrm{MAP}=$ mean arterial pressure $(\mathrm{mmHg}), \mathrm{P} / \mathrm{F}$ ratio $=$ ratio between arterial pressure of oxygen and inspired oxygen concentration $(\mathrm{mmHg}), \mathrm{p}_{\mathrm{a}} \mathrm{CO}_{2}=$ arterial partial pressure of carbon dioxide, $\mathrm{CI}=$ cardiac index $\left(\mathrm{L} / \mathrm{min} / \mathrm{m}^{2}\right)$, lactate $(\mathrm{mmol} / \mathrm{L})$, $\mathrm{RR}=$ respiratory rate $(1 / \mathrm{min}) .{ }^{*}=p<0.05 \mathrm{H} 0$ vs. $\mathrm{H} 6 ; \S=p<0.05$ group A vs. group $\mathrm{C} ; \$=p<0.05$ group $\mathrm{B}$ vs. group C.
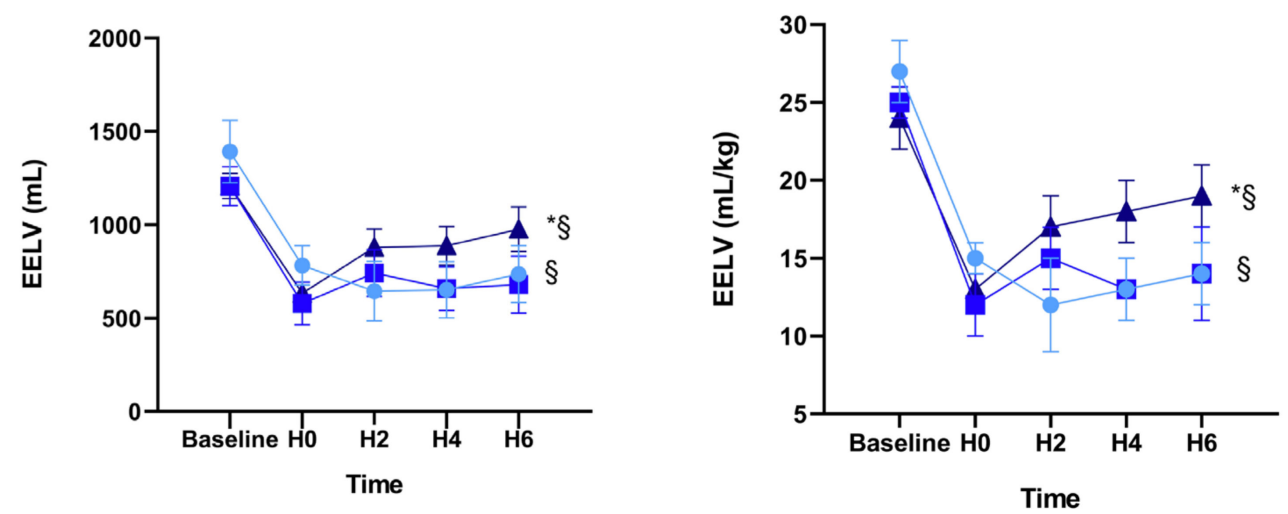

Figure 2. Alterations of end-expiratory lung volume in absolute values and in relation to body weight in response to acute lung injury and intra-abdominal pressure of $10 \mathrm{mmHg}$ over $6 \mathrm{~h}$ of mechanical ventilation. $\bullet$ group A with PEEP: $5 \mathrm{cmH}_{2} \mathrm{O}, \boldsymbol{\square}=$ group B with PEEP: $10 \mathrm{cmH}_{2} \mathrm{O}, \boldsymbol{\Delta}=$ group $\mathrm{C}$ with PEEP: $15 \mathrm{cmH}_{2} \mathrm{O} .{ }^{*}=p<0.05 \mathrm{H} 0$ vs. H6; $\S=p<0.05$ group A vs. group C.
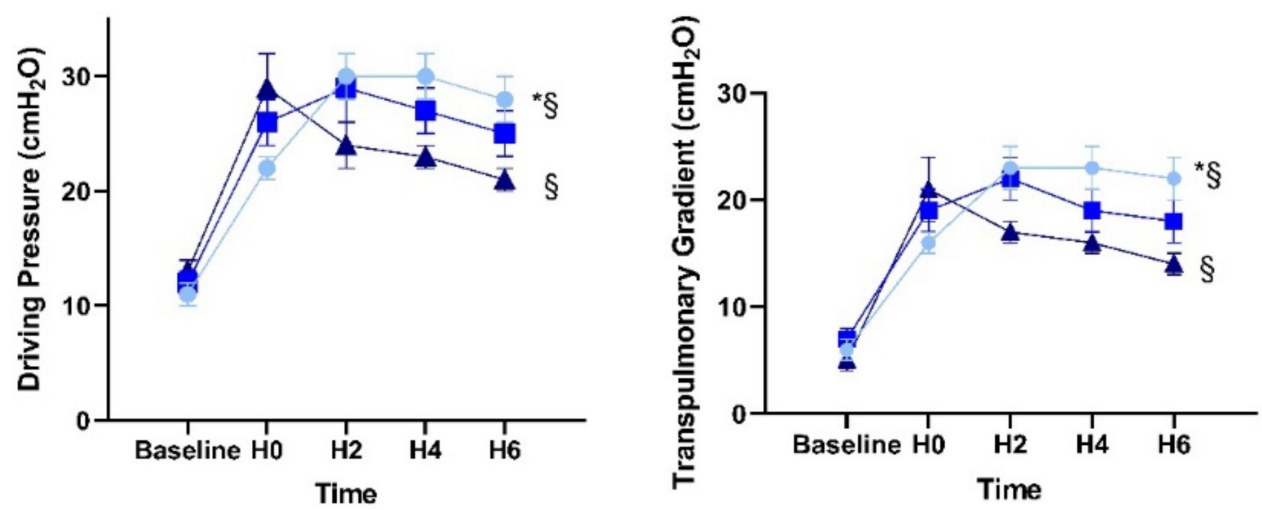

Figure 3. Alterations of driving pressure and transpulmonary gradient in response to acute lung injury and intra-abdominal pressure of $10 \mathrm{mmHg}$ over $6 \mathrm{~h}$ of mechanical ventilation. • = group A with PEEP: $5 \mathrm{cmH}_{2} \mathrm{O}, \mathbf{\square}=$ group $\mathrm{B}$ with PEEP: $10 \mathrm{cmH}_{2} \mathrm{O}, \boldsymbol{\Delta}=$ group $\mathrm{C}$ with PEEP: $15 \mathrm{cmH}_{2} \mathrm{O}$. * $=p<0.05 \mathrm{H} 0$ vs. $\mathrm{H} 6 \S=p<0.05$ group A vs. group $\mathrm{C}$.

The CI was lower in groups B and C between H0 and H6 (4.4 \pm 0.3 vs. $3.9 \pm 0.2$; $p=0.038$ and $5.2 \pm 0.4$ vs. $3.7 \pm 0.1 ; p=0.018)$. Group $C$ received more fluids $(\mathrm{mL})$ than group A $(7125 \pm 573$ vs. $4900 \pm 433 ; p=0.030)$. Despite alterations in the $\mathrm{CI}$, the $\mathrm{P} / \mathrm{F}$ ratio increased in all groups after $6 \mathrm{~h}$. 
The calculated difference in EELV values at $\mathrm{H} 6$ and $\mathrm{H} 0\left(\mathrm{EELV}_{\mathrm{H} 6}-\mathrm{H} 0\right)$ showed the increase of EELV $\mathrm{H6}-\mathrm{H} 0$ at PEEP $15 \mathrm{cmH}_{2} \mathrm{O}$ (group C) and the decrease at PEEP $5 \mathrm{cmH}_{2} \mathrm{O}$ (group A) (group C EELV $\mathrm{H}_{6-\mathrm{H} 0}=343 \pm 113$ vs. group A: $E E V_{\mathrm{H} 6-\mathrm{H} 0}=-46 \pm 115$, $p=0.010$ ) and this also related to body weight (kg) (group C: EELV $/ \mathrm{kg}_{\mathrm{H} 6-\mathrm{H} 0}=7 \pm 2 \mathrm{vs}$. group A: EELV $/ \mathrm{kg}_{\mathrm{H} 6-\mathrm{H} 0}=-1 \pm 2, p=0.015$ ) (Table 3). All animals completed the study.

Table 3. Pulmonary and hemodynamic parameters generated by the subtraction of $\mathrm{H} 0$ from $\mathrm{H} 6$ showing the impact of different PEEP levels over $6 \mathrm{~h}$.

\begin{tabular}{|c|c|c|c|}
\hline & Group A & Group B & Group C \\
\hline $\mathrm{IAP}_{\mathrm{H} 6-\mathrm{H} 0}$ & $7 \pm 1$ & $7 \pm 0$ & $7 \pm 1$ \\
\hline EELV $_{\mathrm{H} 6-\mathrm{H} 0}$ & $-46 \pm 115^{\S}$ & $101 \pm 46$ & $343 \pm 113$ \\
\hline $\mathrm{EELV} / \mathrm{kg}_{\mathrm{H} 6}-\mathrm{H} 0$ & $-1 \pm 2^{\S}$ & $2 \pm 1$ & $7 \pm 2$ \\
\hline$\Delta \mathrm{P}_{\mathrm{H} 6-\mathrm{H} 0}$ & $5 \pm 1^{\S}$ & $0 \pm 1$ & $-8 \pm 4$ \\
\hline$\Delta \mathrm{P}_{\mathrm{LH6}-\mathrm{H} 0}$ & $5 \pm 1 \S$ & $0 \pm 2$ & $-6 \pm 3$ \\
\hline $\mathrm{TPP}_{\text {Insp H6 - H0 }}$ & $5 \pm 2$ & $1 \pm 2$ & $-2 \pm 2$ \\
\hline $\mathrm{TPP}_{\text {Exp H6 - H0 }}$ & $-1 \pm 1 \S$ & $2 \pm 1$ & $4 \pm 1$ \\
\hline $\mathrm{C}_{\text {stat H6-H0 }}$ & $-4 \pm 0^{\S}$ & $0 \pm 1^{\$}$ & $6 \pm 2$ \\
\hline $\mathrm{E}_{\mathrm{RS} \mathrm{H} 6-\mathrm{H} 0}$ & $13 \pm 3 \S$ & $-1 \pm 4$ & $-20 \pm 9$ \\
\hline $\mathrm{E}_{\mathrm{CW}} \mathrm{H} 6-\mathrm{H} 0$ & $0 \pm 1$ & $1 \pm 1^{\$}$ & $-4 \pm 1$ \\
\hline $\mathrm{E}_{\mathrm{LH}} \mathrm{H}-\mathrm{H} 0$ & $13 \pm 3 \S$ & $-2 \pm 4$ & $-16 \pm 9$ \\
\hline $\mathrm{HR}_{\mathrm{H} 6-\mathrm{H} 0}$ & $17 \pm 7$ & $0 \pm 11$ & $-19 \pm 11$ \\
\hline $\mathrm{MAP}_{\mathrm{H} 6-\mathrm{H} 0}$ & $7 \pm 7$ & $1 \pm 5$ & $-7 \pm 8$ \\
\hline $\mathrm{P} / \mathrm{F}$ ratio $\mathrm{H} 6-\mathrm{H} 0$ & $66 \pm 21^{\S}$ & $120 \pm 35$ & $239 \pm 47$ \\
\hline $\mathrm{CI}_{\mathrm{H} 6-\mathrm{H} 0}$ & $-0.3 \pm 0.4^{\S}$ & $-0.4 \pm 0.2$ & $-1.5 \pm 0.4$ \\
\hline Lactate $_{\mathrm{H} 6-\mathrm{H} 0}$ & $-0.7 \pm 0.3$ & $-0.7 \pm 0.1$ & $-0.8 \pm 0.3$ \\
\hline
\end{tabular}

Data are expressed as mean \pm SEM. IAP $=$ intra-abdominal pressure $(\mathrm{mmHg})$, EELV $=$ end-expiratory lung volume $(\mathrm{mL}), \mathrm{EELV} / \mathrm{kg}=$ end-expiratory lung volume per $\mathrm{kg}$ bodyweight $(\mathrm{mL} / \mathrm{kg}), \Delta \mathrm{P}=$ driving pressure $\left(\mathrm{cmH}_{2} \mathrm{O}\right), \Delta \mathrm{P}_{\mathrm{L}}=$ transpulmonary pressure $\left(\mathrm{cmH}_{2} \mathrm{O}\right), \mathrm{TPP}_{\text {Insp }}=$ inspiratory transpulmonary pressure $\left(\mathrm{cmH}_{2} \mathrm{O}\right)$ $\mathrm{TPP}_{\mathrm{Exp}}=$ expiratory transpulmonary pressure $\left(\mathrm{cmH}_{2} \mathrm{O}\right), \mathrm{C}_{\text {Stat }}=$ static pulmonary compliance $\left(\mathrm{mL} / \mathrm{cmH}_{2} \mathrm{O}\right)$, $\mathrm{E}_{\mathrm{RS}}=$ elastance of the respiratory system $\left(\mathrm{cmH}_{2} \mathrm{O} / \mathrm{mL}\right), \mathrm{E}_{\mathrm{CW}}=$ elastance of the chest wall $\left(\mathrm{cmH}_{2} \mathrm{O} / \mathrm{mL}\right), \mathrm{EL}=$ lung elastance $\left(\mathrm{cmH}_{2} \mathrm{O} / \mathrm{mL}\right), \mathrm{HR}=$ heart rate (beats $\left./ \mathrm{min}\right), \mathrm{MAP}=$ mean arterial pressure $(\mathrm{mmHg}), \mathrm{P} / \mathrm{F}$ ratio $=$ ratio between arterial pressure of oxygen and inspired oxygen concentration $(\mathrm{mmHg}), \mathrm{CI}=$ cardiac index $\left(\mathrm{L} / \mathrm{min} / \mathrm{m}^{2}\right)$, lactate $(\mathrm{mmol} / \mathrm{L}) . \S=p<0.05$ group A vs. group C. $\$=p<0.05$ group B vs. group C.

\section{Lung Injury Score and Wet-Dry Weight Ratio (W/D)}

The global lung injury score did not differ between the groups (A: $0.25 \pm 0.05$, B: $0.21 \pm 0.02, C: 0.22 \pm 0.03 ; p=0.520$ ) (Supplementary Figure S1).

The wet-dry weight ratios (W/D) also did not differ between groups (A: $1.64 \pm 0.27$, B: $1.98 \pm 0.46, C: 1.95 \pm 0.29 ; p=0.391)$.

\section{Discussion}

\subsection{Main Findings}

The present animal study demonstrated that a PEEP of $15 \mathrm{cmH}_{2} \mathrm{O}$ in cases of moderately elevated IAP seems to improve oxygenation by increasing the EELV without aggravating the lung injury in piglets with saline lavage-induced ALI.

\subsection{Lung Injury Model and Elevated Intra-Abdominal Pressure}

Our study involved the use of a triple hit porcine model. Up to $25 \%$ of mechanical ventilated patients on an intensive care unit (ICU) have ARDS [12]. This acute lung injury model was established by repeated saline lung lavages and non-protective ventilation-the classical model used to simulate human ARDS in an animal [21,24]. The third hit was a 
moderately elevated IAP, established by using an intra-abdominal balloon filled with water. This model should be representative of critically ill patients in an ICU as the mean IAP in these patients is around $10 \mathrm{mmHg}$ [1]. We thus tried to simulate a well-known situation in critically ill patients. Lima et al. found that a $3 \mathrm{~h}$ exposure to an IAP of $15 \mathrm{mmHg}$ was sufficient to cause alveolar collapse, hemorrhage, interstitial edema, and neutrophil infiltration in the lungs and increased lung cell apoptosis despite the application of lungprotective ventilation in a study of 20 rats [10]. Our group recently showed that an IAP of $10 \mathrm{mmHg}$ in a porcine study over $6 \mathrm{~h}$ caused lung injury which can be reduced by the application of PEEP [22].

In 2012, Regli et al. [7] carried out a porcine study with IAH and ALI in a different setting. They induced ALI by oleic acid and randomly applied three different IAP (3, 18 and $22 \mathrm{mmHg}$ ) by filling an intra-abdominal balloon with air to study the effects of different PEEP settings (baseline PEEP $\left(5 \mathrm{cmH}_{2} \mathrm{O}\right)$, moderate PEEP $\left(0.5 \times\right.$ IAP in $\left.\mathrm{cmH}_{2} \mathrm{O}\right)$ and high PEEP $\left(1.0 \times\right.$ IAP in $\left.\left.\mathrm{cmH}_{2} \mathrm{O}\right)\right)$ in short time alterations [7]. Their study supported the application of PEEP in the setting of acute lung injury and IAH matched to the IAP in short time experiments. We filled the balloon with warm water. The effect of this on the cephalad shift of the diaphragm was, from our point of view, a more pathophysiological approach (e.g., ascites, abdominal distension, fluid overload) [3]. There are limited data to show at what level of IAP lung volumes reduce or atelectasis occurs. Regli et al. showed in different studies that at least in pigs, lung volumes decline with an increasing degree of IAH [6,7]. The experimental setting of Mutoh et al. in piglets involved the inflation of an abdominal balloon in small increments and they found that end-expiratory lung volumes (EELV) reduced even after small increases in IAP (ranged from 13, 14, 15 to finally $16 \mathrm{cmH}_{2} \mathrm{O}$ ) [25]. In our model, we were able to show that even a moderate IAP of $10 \mathrm{mmHg}$ caused changes in alveolar mechanics when applied over $6 \mathrm{~h}$ [22].

In our study, the P/F ratio improved over the $6 \mathrm{~h}$ of study protocol after the triple-hit model was established in all groups. The difference over time was more profound with increasing PEEP. Interestingly, it looks like IAH has a severe effect on oxygenation only in injured lungs $[7,26]$. Oxygenation, as a target for PEEP optimization during mechanical ventilation, has become widely accepted in clinical routine. Thus, the ARDS network table, which contains relatively fixed combinations of $\mathrm{F}_{\mathrm{i}} \mathrm{O}_{2}$ and PEEP, is commonly used at the bedside, although individual lung mechanics are not considered [27]. For instance, atelectrauma could not be identified by oxygenation in an experimental model of acute lung injury [28].

\subsection{Alterations in Lung Mechanics}

The main aim of our study was to describe the alterations in EELV and $\triangle \mathrm{P}_{\mathrm{L}}$ in an ALI porcine model of moderately elevated IAP. Stress (the transpulmonary pressure $\left(\Delta \mathrm{P}_{\mathrm{L}}\right)$ ) and strain (the applied tidal volume per end-expiratory lung volume $\left(\mathrm{V}_{\mathrm{T}} / \mathrm{EELV}\right)$ ) are crucial parameters for the development and prevention of ventilator-induced lung injury (VILI) [29,30]. Unfortunately, neither parameter is routinely measured at the bedside [12]. We detected a further drop of EELV and EELV $/ \mathrm{kg}$ bw with a PEEP of $5 \mathrm{cmH}_{2} \mathrm{O}$ over time in our study. In the two groups with a PEEP of 10 and $15 \mathrm{cmH}_{2} \mathrm{O}$, these reductions were not observed. The experimental study of Steinberg et al. showed that PEEP converted abnormal, unstable alveoli into normal functioning, stable alveoli and PEEP-induced alveolar stabilization reduced lung damage [31]. An increase in PEEP may have caused progressive distention in the conducting airways rather than increasing alveolar area and stability [28]. Measuring EELV might be an attractive method to adjust PEEP appropriately for patients in ICU.

After the induction of the triple-hit model, our results showed increased values in $\Delta \mathrm{P}_{\mathrm{L}}$ as well as in $\Delta \mathrm{P}$, a surrogate for $\Delta \mathrm{P}_{\mathrm{L}}$. Obviously, during six hours of mechanical ventilation, $\Delta \mathrm{P}_{\mathrm{L}}$ as well as $\Delta \mathrm{P}$ decreased with a PEEP of $15 \mathrm{cmH}_{2} \mathrm{O}$, while the opposite was seen in the group with PEEP of $5 \mathrm{cmH}_{2} \mathrm{O}$. As $\triangle \mathrm{P}$ is a predictor of mortality in ARDS patients, a reduction of $\triangle \mathrm{P}$ and $\Delta \mathrm{P}_{\mathrm{L}}$ by PEEP seems to be a lung protective approach [32]. 
Previous investigations confirmed an increase in peak and plateau airway pressures proportionally with increasing IAP [33,34]. In a pig model of IAH, increasing intraabdominal volume has also been shown to exponentially increase peak airway pressure [35]. In injured porcine lungs with elevated IAP, the $\mathrm{E}_{\mathrm{RS}}$ is not only influenced by alterations of the $\mathrm{E}_{\mathrm{CW}}$, but also by alterations in $\mathrm{E}_{\mathrm{L}}$. Our study demonstrated that at the end of a $6 \mathrm{~h}$ mechanical ventilation, $\mathrm{E}_{\mathrm{RS}}$ decreased with increasing PEEP mainly due to the decrease in $\mathrm{E}_{\mathrm{L}}$ with raising PEEP, but $E_{C W}$ was nearly the same in all groups. Similar results were shown in patients. Krebs et al. applied different PEEP levels (up to $20 \mathrm{cmH}_{2} \mathrm{O}$ ) in 20 patients with ARDS. One half of the study population had IAH (with a mean IAP of 8 and $16 \mathrm{mmHg}$, respectively) [36]. PEEP was found to decrease $\mathrm{E}_{\mathrm{RS}}$ by decreasing $\mathrm{E}_{\mathrm{L}}$ without influencing $\mathrm{E}_{\mathrm{CW}}$ in both groups.

\subsection{Limitations}

This is an animal study with an artificially induced lung injury. The results therefore cannot be applied to human patients without any restrictions. We only used an IAP of $10 \mathrm{mmHg}$ and PEEP of 5, 10 and $15 \mathrm{cmH}_{2} \mathrm{O}$. Hence, it is unclear to what extent the above-mentioned PEEP values matching to IAP is useful and would be tolerated at higher IAP values. Despite lower values for stress and strain, we could not find differences in histological lung injury score (Supplementary Figure S1). This might be due to a short ventilation time or mild differences between the groups.

It is still not clear if the PEEP strategies as used in our study affected acute lung injury. This is because the changes in lung mechanics and gas exchange were not accompanied by changes in the lung injury score or W/D. This discrepancy could perhaps be due to the low sensitivity of injury scores and W/D, which sometimes shows no change when other markers of inflammation and permeability disruption such as broncho-alveolarlavage (BAL) cellularity or high molecular weight protein concentrations reach significance. Alternatively, it could be due to the lack of certain controls (W/D) and scores in pigs at H0. Perhaps the oxygenation and lung mechanic changes were unrelated to the actual injury, and instead due to variations in the severity of micro-atelectasis or other factors.

\section{Conclusions}

We studied different PEEP levels in a model of ALI and elevated IAP. In the group with a PEEP of $5 \mathrm{cmH}_{2} \mathrm{O}$ applied over $6 \mathrm{~h}, \Delta \mathrm{P}$ and $\Delta \mathrm{P}_{\mathrm{L}}$ increased further over time. This was not the case in the groups with a PEEP of 10 and $15 \mathrm{cmH}_{2} \mathrm{O}$. Only in the group with a PEEP of $15 \mathrm{cmH}_{2} \mathrm{O}$, the EELV and EELV / $\mathrm{kg}$ bw increased significantly over time. Although $\Delta \mathrm{P}$ and $\Delta \mathrm{P}_{\mathrm{L}}$ were significantly lower at $\mathrm{H} 6$ in group $\mathrm{C}$ compared to group $\mathrm{A}$, we could not show significant differences in histological lung injury score nor in the wet/dry ratio of the lungs between the groups.

Supplementary Materials: The following are available online at https:/ / www.mdpi.com/2077-038 3/10/2/306/s1, Figure S1: Histologic assessment of lung injury, Figure S2: The Lung Injury Scoring System.

Author Contributions: M.O.F., A.K., and E.S. conceived and designed research; M.O.F., A.K., E.S., D.D., A.H., M.B. and B.L.D. performed experiments; M.O.F., A.K. and E.S. analyzed data; M.O.F., A.K., E.S., and B.L.D. interpreted results of experiments; E.S. and D.D. prepared figures; M.O.F. drafted manuscript; M.O.F., A.K., M.D., F.U. and M.A.W. edited and revised manuscript; M.O.F., E.S., B.L.D., D.D., A.H., M.B., M.D., F.U., M.A.W. and A.K. approved final version of manuscript. All authors have read and agreed to the published version of the manuscript.

Funding: Study was financed by Hospital Bergstrasse and Heidelberg University Hospital.

Institutional Review Board Statement: The protocol was approved by the responsible committee for animal research (Regierungspräsidium Karlsruhe, No. 35-9185.81/G-161/17).

Informed Consent Statement: Not applicable. 
Data Availability Statement: The data presented in this study are available on request from the corresponding author.

Acknowledgments: We would like to thank the Svenja Schueler Institute for medical biometry and informatics and Heidelberg University Hospital, Heidelberg, Germany, for statistical advice.

Conflicts of Interest: The authors declare no conflict of interest.

\section{Abbreviations}

$\begin{array}{ll}\text { ALI } & \text { Acute lung injury } \\ \text { ARDS } & \text { Acute Respiratory Distress Syndrome } \\ \text { BAL } & \text { Broncho-alveolar-lavage } \\ \text { CI } & \text { Cardiac index } \\ \mathrm{C}_{\text {stat }} & \text { Static lung compliance } \\ \text { EELV } & \text { End-expiratory lung volume } \\ \mathrm{E}_{\mathrm{L}} & \text { Elastance of the lung } \\ \mathrm{E}_{\mathrm{RS}} & \text { Elastance of the respiratory system } \\ \mathrm{HR} & \text { Heart rate } \\ \mathrm{IAH} & \text { Intra-abdominal hypertension } \\ \mathrm{IAP} & \text { Intra-abdominal pressure } \\ \mathrm{IQR} & \text { Interquartile range } \\ \mathrm{MAP} & \text { Mean arterial pressure } \\ \Delta \mathrm{P} & \text { Driving pressure } \\ \Delta \mathrm{P}_{\mathrm{L}} & \text { Transpulmonary pressure } \\ \mathrm{P}_{\mathrm{Es}} & \text { Esophageal pressure } \\ \mathrm{PEEP} & \text { Positive end-expiratory pressure } \\ \mathrm{P}_{\mathrm{Es}} & \text { Inspiratory esophageal pressure } \\ \mathrm{P}_{\mathrm{EsExp}} & \text { End-expiratory esophageal pressure } \\ \mathrm{P} / \mathrm{F} \text { ratio } & \text { PaO } / \text { FiO } 2 \text { ratio } \\ \mathrm{RR} & \text { Respiratory rate } \\ \mathrm{TPP} & \text { Transpulmonary expiratory pressure } \\ \mathrm{TPP} & \text { Transpulmonary inspiratory pressure } \\ \mathrm{VILI} & \text { Ventilator-induced lung injury } \\ \mathrm{W} / \mathrm{D} & \text { Wet-to-dry ratio } \\ & \end{array}$

\section{References}

1. Malbrain, M.L.; Chiumello, D.; Pelosi, P.; Bihari, D.; Innes, R.; Ranieri, V.M.; Del Turco, M.; Wilmer, A.; Brienza, N.; Malcangi, V.; et al. Incidence and prognosis of intraabdominal hypertension in a mixed population of critically ill patients: A multiple-center epidemiological study. Crit. Care Med. 2005, 33, 315-322. [CrossRef]

2. Pelosi, P.; Quintel, M.; Malbrain, M.L. Effect of intra-abdominal pressure on respiratory mechanics. Acta Clin. Belg. 2007, 62, 78-88. [CrossRef] [PubMed]

3. Regli, A.; Pelosi, P.; Malbrain, M. Ventilation in patients with intra-abdominal hypertension: What every critical care physician needs to know. Ann. Intensive Care 2019, 9, 52. [CrossRef] [PubMed]

4. Zhou, J.C.; Xu, Q.P.; Pan, K.H.; Mao, C.; Jin, C.W. Effect of increased intra-abdominal pressure and decompressive laparotomy on aerated lung volume distribution. J. Zhejiang Univ. Sci. B 2010, 11, 378-385. [CrossRef]

5. Gattinoni, L.; Pelosi, P.; Suter, P.M.; Pedoto, A.; Vercesi, P.; Lissoni, A. Acute respiratory distress syndrome caused by pulmonary and extrapulmonary disease. Different syndromes? Am. J. Respir. Crit. Care Med. 1998, 158, 3-11. [CrossRef] [PubMed]

6. Regli, A.; Hockings, L.E.; Musk, G.C.; Roberts, B.; Noffsinger, B.; Singh, B.; van Heerden, V.P. Commonly applied positive end-expiratory pressures do not prevent functional residual capacity decline in the setting of intra-abdominal hypertension: A pig model. Crit. Care 2010, 14, R128. [CrossRef]

7. Regli, A.; Chakera, J.; De Keulenaer, B.L.; Roberts, B.; Noffsinger, B.; Singh, B.; van Heerden, V.P. Matching positive endexpiratory pressure to intra-abdominal pressure prevents end-expiratory lung volume decline in a pig model of intra-abdominal hypertension. Crit. Care Med. 2012, 40, 1879-1886. [CrossRef]

8. Vidal, M.G.; Ruiz Weisser, J.; Gonzalez, F.; Toro, M.A.; Loudet, C.; Balasini, C.; Canales, H.; Reina, R.; Estenssoro, E. Incidence and clinical effects of intra-abdominal hypertension in critically ill patients. Crit. Care Med. 2008, 36, 1823-1831. [CrossRef] [PubMed]

9. Reintam Blaser, A.; Parm, P.; Kitus, R.; Starkopf, J. Risk factors for intra-abdominal hypertension in mechanically ventilated patients. Acta Anaesthesiol. Scand. 2011, 55, 607-614. [CrossRef] 
10. Lima, R.; Silva, P.L.; Capelozzi, V.L.; Oliveira, M.G.; Santana, M.C.E.; Cruz, F.F.; Pelosi, P.; Schanaider, A.; Malbrain, M.; Rocco, P.; et al. Early impact of abdominal compartment syndrome on liver, kidney and lung damage in a rodent model. Anaesthesiol. Intensive Ther. 2017, 49, 130-138. [CrossRef]

11. Pelosi, P.; Vargas, M. Mechanical ventilation and intra-abdominal hypertension: 'Beyond Good and Evil'. Crit. Care 2012, 16, 187. [CrossRef] [PubMed]

12. Bellani, G.; Laffey, J.G.; Pham, T.; Fan, E.; Brochard, L.; Esteban, A.; Gattinoni, L.; Van Haren, F.; Larsson, A.; McAuley, D.F.; et al. Epidemiology, Patterns of Care, and Mortality for Patients with Acute Respiratory Distress Syndrome in Intensive Care Units in 50 Countries. JAMA 2016, 315, 788-800. [CrossRef] [PubMed]

13. Sklar, M.C.; Patel, B.K.; Beitler, J.R.; Piraino, T.; Goligher, E.C. Optimal Ventilator Strategies in Acute Respiratory Distress Syndrome. Semin. Respir. Crit. Care Med. 2019, 40, 81-93. [CrossRef] [PubMed]

14. Baydur, A.; Behrakis, P.K.; Zin, W.A.; Jaeger, M.; Milic-Emili, J. A simple method for assessing the validity of the esophageal balloon technique. Am. Rev. Respir. Dis. 1982, 126, 788-791.

15. Lachmann, B.; Robertson, B.; Vogel, J. In vivo lung lavage as an experimental model of the respiratory distress syndrome. Acta Anaesthesiol. Scand. 1980, 24, 231-236. [CrossRef]

16. Grieco, D.L.; Chen, L.; Brochard, L. Transpulmonary pressure: Importance and limits. Ann. Transl. Med. 2017, 5, 285. [CrossRef]

17. Olegard, C.; Sondergaard, S.; Houltz, E.; Lundin, S.; Stenqvist, O. Estimation of functional residual capacity at the bedside using standard monitoring equipment: A modified nitrogen washout/washin technique requiring a small change of the inspired oxygen fraction. Anesth. Analg. 2005, 101, 206-212. [CrossRef]

18. Malbrain, M.L.; Deeren, D.H. Effect of bladder volume on measured intravesical pressure: A prospective cohort study. Crit. Care. 2006, 10, R98. [CrossRef]

19. Kirkpatrick, A.W.; Roberts, D.J.; De Waele, J.; Jaeschke, R.; Malbrain, M.L.; De Keulenaer, B.; Duchesne, J.; Bjorck, M.; Leppaniemi, A.; Ejike, J.C.; et al. Intra-abdominal hypertension and the abdominal compartment syndrome: Updated consensus definitions and clinical practice guidelines from the World Society of the Abdominal Compartment Syndrome. Intensive Care Med. 2013, 39, 1190-1206. [CrossRef]

20. Jakob, S.M.; Knuesel, R.; Tenhunen, J.J.; Pradl, R.; Takala, J. Increasing abdominal pressure with and without PEEP: Effects on intra-peritoneal, intra-organ and intra-vascular pressures. BMC Gastroenterol. 2010, 10, 70. [CrossRef]

21. Matute-Bello, G.; Downey, G.; Moore, B.B.; Groshong, S.D.; Matthay, M.A.; Slutsky, A.S.; Kuebler, W.M. An official American Thoracic Society workshop report: Features and measurements of experimental acute lung injury in animals. Am. J. Respir. Cell Mol. Biol. 2011, 44, 725-738. [CrossRef] [PubMed]

22. Fiedler, M.O.; Deutsch, B.L.; Simeliunas, E.; Diktanaite, D.; Harms, A.; Brune, M.; Uhle, F.; Weigand, M.; Brenner, T.; Kalenka, A. Effect of moderate elevated intra-abdominal pressure on lung mechanics and histological lung injury at different positive end-expiratory pressures. PLoS ONE 2020, 15, e0230830. [CrossRef] [PubMed]

23. Faul, F.; Erdfelder, E.; Lang, A.-G.; Buchner, A. G*Power 3: A flexible statistical power analysis program for the social, behavioral, and biomedical sciences. Behav. Res. Methods 2007, 39, 175-191. [CrossRef] [PubMed]

24. Martin, T.R.; Matute-Bello, G. Experimental models and emerging hypotheses for acute lung injury. Crit. Care Clin. 2011, 27, 735-752. [CrossRef]

25. Mutoh, T.; Lamm, W.J.; Embree, L.J.; Hildebrandt, J.; Albert, R.K. Volume infusion produces abdominal distension, lung compression, and chest wall stiffening in pigs. J. Appl. Physiol. 1992, 72, 575-582. [CrossRef]

26. Quintel, M.; Pelosi, P.; Caironi, P.; Meinhardt, J.P.; Luecke, T.; Herrmann, P.; Taccone, P.; Rylander, C.; Valenza, F.; Carlesso, E.; et al. An increase of abdominal pressure increases pulmonary edema in oleic acid-induced lung injury. Am. J. Respir. Crit. Care Med. 2004, 169, 534-541. [CrossRef]

27. Hochhausen, N.; Biener, I.; Rossaint, R.; Follmann, A.; Bleilevens, C.; Braunschweig, T.; Leonhardt, S.; Czaplik, M. Optimizing PEEP by Electrical Impedance Tomography in a Porcine Animal Model of ARDS. Respir. Care 2017, 62, 340-349. [CrossRef]

28. Andrews, P.L.; Sadowitz, B.; Kollisch-Singule, M.; Satalin, J.; Roy, S.; Snyder, K.; Gatto, L.A.; Nieman, G.F.; Habashi, N.M. Alveolar instability (atelectrauma) is not identified by arterial oxygenation predisposing the development of an occult ventilator-induced lung injury. Intensive Care Med. Exp. 2015, 3, 54. [CrossRef]

29. Slutsky, A.S.; Ranieri, V.M. Ventilator-induced lung injury. N. Engl. J. Med. 2013, 369, 2126-2136. [CrossRef]

30. Silva, P.L.; Negrini, D.; Rocco, P.R. Mechanisms of ventilator-induced lung injury in healthy lungs. Best Pract. Res. Clin. Anaesthesiol. 2015, 29, 301-313. [CrossRef]

31. Steinberg, J.M.; Schiller, H.J.; Halter, J.M.; Gatto, L.A.; Lee, H.M.; Pavone, L.A.; Nieman, G.F. Alveolar instability causes early ventilator-induced lung injury independent of neutrophils. Am. J. Respir. Crit. Care Med. 2004, 169, 57-63. [CrossRef] [PubMed]

32. Amato, M.B.; Meade, M.O.; Slutsky, A.S.; Brochard, L.; Costa, E.L.; Schoenfeld, D.A.; Stewart, T.E.; Briel, M.; Talmor, D.; Mercat, A.; et al. Driving pressure and survival in the acute respiratory distress syndrome. N. Engl. J. Med. 2015, 372, 747-755. [CrossRef] [PubMed]

33. Torquato, J.A.; Lucato, J.J.; Antunes, T.; Barbas, C.V. Interaction between intra-abdominal pressure and positive-end expiratory pressure. Clinics (Sao Paulo) 2009, 64, 105-112. [CrossRef] [PubMed]

34. De Keulenaer, B.L.; De Waele, J.J.; Powell, B.; Malbrain, M.L. What is normal intra-abdominal pressure and how is it affected by positioning, body mass and positive end-expiratory pressure? Intensive Care Med. 2009, 35, 969-976. [CrossRef] 
35. Regli, A.; De Keulenaer, B.L.; Singh, B.; Hockings, L.E.; Noffsinger, B.; van Heerden, P.V. The respiratory pressure-abdominal volume curve in a porcine model. Intensive Care Med. Exp. 2017, 5, 11. [CrossRef]

36. Krebs, J.; Pelosi, P.; Tsagogiorgas, C.; Alb, M.; Luecke, T. Effects of positive end-expiratory pressure on respiratory function and hemodynamics in patients with acute respiratory failure with and without intra-abdominal hypertension: A pilot study. Crit. Care 2009, 13, R160. [CrossRef] 